Кормовые ферментативные гидролизаты

\title{
КОНВЕРСИЯ ПОЛИМЕРОВ ЗЕРНА ПШЕНИЦЫ И КУКУРУЗЫ ПОД ВЛИЯНИЕМ ФИТОЛИТИЧЕСКИХ И ПРОТЕОЛИТИЧЕСКИХ ФЕРМЕНТОВ*
}

\author{
Л.В. РИМАРЕВА, М.Б. ОВЕРЧЕНКО, Е.М. СЕРБА ${ }^{\bowtie}$, Н.И. ИГНАТОВА, \\ Н.В. ШЕЛЕХОВА
}

В состав зерна, помимо крахмала, гемицеллюлоз и белка, входят фитиновая кислота и ее соли. Показано, что фитазы способствуют высвобождению фосфора, улучшению переваримости питательных веществ кормов, повышению мясной продуктивности животных и птицы. В то же время мало изучено каталитическое действие фитаз и протеаз на степень деструкции полисахаридов и белковых полимеров зернового сырья, высвобождение катионов и анионов, особенно при приготовлении зернового сусла в производстве спирта. В представленной работе мы впервые показали, что в результате фитолитического действия в зерновом сусле происходит не только высвобождение фосфатов и катионов металлов, но и увеличение концентрации анионов органических солей. Совместное действие фитолитических и протеолитических ферментов на полимеры зернового сырья повышает степень их каталитической деструкции с образованием растворимых форм углеводов, азотистых веществ, катионов и анионов, способствует получению обогащенного зернового сусла с хорошими реологическими свойствами. Целью работы была оценка эффективности влияния ферментных препаратов фитолитического и протеолитического действия на конверсию высокомолекулярных полимеров пшеничного и кукурузного сырья в процессе приготовления зернового сусла. Объектами исследования служили зерно пшеницы (Triticum sp.) и кукурузы (Zea mays). Зерновое сусло готовили в колбах Эрленмейера, содержащих 50 г зерновой муки и $150 \mathrm{~cm}^{3}$ воды и помещенных в водяную баню. На стадии приготовления зернового замеса для декстринизации крахмала применяли термостабильную $\alpha$-амилазу из расчета 0,6 ед. АС/г крахмала. Для получения зернового сусла осахаривание крахмала и гидролиз некрахмальных полисахаридов в контроле осуществляли ферментными препаратами - источниками глюкоамилазы $(9,0$ ед. ГлС/г крахмала) и ксиланазы (0,15 ед. КС/г сырья). В опытных вариантах вводили ферментный препарат, содержащий фитазу (от 1,0 до 2,5 ед. ФС/г сырья), а также ФП протеолитического действия (0,1 ед. ПС/г сырья). Состав основных полимеров зернового сырья, концентрацию зернового сусла, содержание редуцирующих углеводов (РВ) определяли согласно инструкции технохимического контроля спиртового производства, концентрацию аминного азота $\left(\mathrm{NH}^{+}\right)-$методом, основанным на способности аминокислот образовывать растворимые медные соединения с суспензией фосфорнокислой меди. Динамическую вязкость зернового сусла оценивали посредством вибрационной вискозиметрии. Изучение ионного состава зернового замеса и сусла проводили, используя систему капиллярного электрофореза серии PrinCE-560 («PrinCE Technologies B.V.», Нидерланды), оснащенную кондуктометрическим детектором. Установлено, что использование фитолитических ферментов способствовало снижению вязкости пшеничного и кукурузного сусла более чем на $20 \%$, увеличению количества редуцирующих углеводов - на 9,5-11,3 \%, повышению количества высвобождаемых ионов - в 2,1-2,4 раза. Содержание аминного азота в сусле существенно не изменялось. Показано, что в результате фитолитического действия повышалась концентрация анионов органических солей, таких как оксалаты, малаты, цитраты и сукцинаты в пшеничном сусле и оксалаты, малаты, цитраты и лактаты в кукурузном сусле. Выявлено более существенное влияние фитазы при подготовке сусла из кукурузы: концентрация фосфатов в питательной среде увеличилась в 3,9 раза (в пшеничном сусле - в 1,6 раза), ионов калия и магния - на 12 и $22 \%$ по сравнению с аналогичными показателями в контроле. Подобрана оптимальная дозировка фитазы (1,5 ед/г сырья), обеспечивающая максимальное высвобождение ионов, идентифицированных методом капиллярного электрофореза, и эффективную конверсию полисахаридов, белковых и фитиновых веществ зерна. Биокаталитическая обработка зерна комплексом ферментов, который наряду с амилазами и ксиланазой включал фитазу и протеазы, способствовала повышению в пшеничном и кукурузном сусле концентрации редуцирующих углеводов на 16,8 и 18,8 \%, аминного азота - в 1,7 и 1,9 раза, снижению вязкости - на 41,7 и $44,7 \%$.

Ключевые слова: фитаза, протеаза, пшеничное и кукурузное сырье, биокатализ, ионы, катионы, фосфор, зерновое сусло.

\section{Агропромышленный комплекс Российской Федерации ежегодно}

\footnotetext{
* Исследования проведены за счет средств субсидии на выполнение государственного задания в рамках

Программы Фундаментальных научных исследований государственных академий наук (тема № 05292019-0066).
} 
перерабатывает более 100 млн т сельскохозяйственного сырья. К крупномасштабным потребителям зерна относятся спиртовое, крахмалопаточное, пивоваренное и кормовое производства. Для повышения их рентабельности создаются инновационные ресурсосберегающие технологии, способствующие решению экологических проблем перерабатывающих отраслей и производству конкурентоспособной пищевой и кормовой продукции (1-3). Эффективность этих технологий достигается посредством разработки биокатализаторов с широкой субстратной специфичностью, обеспечивающих глубокий гидролиз высокомолекулярных полимеров зернового сырья (4-6). Как показали результаты предыдущих исследований, синергизм действия амилолитических, протеолитических и гемицеллюлазных ферментов способствовал повышению качества зернового сусла, обогащению его углеводами, азотистыми веществами, повышению выхода целевой продукции (4).

В состав зерна помимо традиционных составляющих (крахмала, гемицеллюлоз, целлюлозы и белков) входит фитиновая кислота и ее соли (фитаты), в виде которых минеральный фосфор в основном содержится в растениях (7-9). Количество фитиновых соединений в зерне различается в зависимости от вида культуры, сорта семян и условий произрастания. Показано, что в пшенице оно варьирует от 0,4 до 3,9 \%, в кукурузе - от 0,7 до $2,8 \%(10,11)$. При этом около $80 \%$ фосфора находится в связанном состоянии, поскольку он встроен в молекулу мио-инозитгексафосфорной кислоты, которая блокирует его, делая недоступным для живого организма $(12,13)$. Кроме того, фитаты, проявляя высокий отрицательный заряд, связывают не только фосфор, но и катионы металлов $(9,14,15)$, а также образуют достаточно прочные комплексы с белками и углеводами $(16,17)$. Фитолитическое воздействие позволяет высвободить ценные компоненты сырья и повысить его биодоступность (13).

Фитаза, присутствующая в растениях в процессе их роста, способствует каталитическому расщеплению фитиновой кислоты (18), однако ее количества недостаточно для полного высвобождения фосфора. Все большее внимание привлекают фитолитические ферменты, синтезируемые микроорганизмами. Наиболее перспективные продуценты - грибы рода Aspergillus (6), рекомбинантные штаммы дрожжей и бактерий (19-21).

В последнее время исследуется эффективность каталитического действия фитаз при переработке зернового сырья в различных отраслях АПК. Существенное внимание уделено использованию фитазы для улучшения переваримости питательных веществ кормов. Согласно полученным данным, применение фитолитических ферментов способствует распаду фитиновых соединений, высвобождению фосфора и других микроэлементов, что приводит к повышению роста и мясной продуктивности животных и птицы (22-24). Достаточно широко рассмотрены процессы взаимодействия фитиновой кислоты и ее солей с веществами, входящими в состав пищевого сырья и продуктов питания $(16,17,24-26)$.

Авторы, исследовавшие влияние фитазы при подготовке зерна сорго и кукурузы для производства лагерного пива, показали потенциальную возможность улучшения условий питания дрожжей при сбраживании зернового сусла $(8,10,27,28)$. Подтверждено, что в условиях анаэробного брожения фосфор усваивается дрожжами, главным образом в начальной фазе. Молодые активно размножающиеся дрожжевые клетки содержали в 2 раза больше фосфора, чем к концу брожения. Однако эффективность каталитического действия фитаз при переработке зернового сырья в производстве спирта практически не исследовалась, особенно в составе комплекса 
гидролитических ферментов, обладающих различной субстратной специфичностью (4). Получены только предварительные данные о положительном влиянии фитазы, синтезированной грибом Aspergillus awamori, на процессы генерации дрожжей и спиртового брожения при получении зернового сусла (28).

В представленной работе мы впервые показали, что в результате фитолитического действия в зерновом сусле не только высвобождаются фосфаты и катионы металлов, но и увеличивается концентрация анионов органических солей. Выявлено, что совместное действие фитолитических и протеолитических ферментов на полимеры зернового сырья повышает степень их каталитической деструкции с образованием растворимых форм углеводов, азотистых веществ, катионов и анионов, способствует получению обогащенного зернового сусла с хорошими реологическими свойствами. На этом основании предложен оптимальный состав ферментативного комплекса, обеспечивающий эффективный гидролиз полисахаридов, фитиновых и белковых веществ перерабатываемого сырья и максимальное накопление редуцирующих углеводов, аминного азота, фосфатов и минералов в биодоступной форме.

Целью работы была оценка эффективности влияния ферментных препаратов фитолитического и протеолитического действия на конверсию высокомолекулярных полимеров пшеничного и кукурузного сырья в процессе приготовления зернового сусла.

Методика. Работа выполнялась на базе Всероссийского НИИ пищевой биотехнологии - филиал ФГБУН ФИЦ питания и биотехнологии в 2019-2020 годах. Объектами исследования служили зерно пшеницы (Triticum sp.) и кукурузы (Zea mays L.). Использовали традиционные для спиртового производства ферментные препараты (ФП) с различной субстратной специфичностью: Amylex 5T («Genencor», США) - источник термостабильной $\alpha$-амилазы (ферментная активность AC 2000 ед/см ${ }^{3}$ ), Diazyme

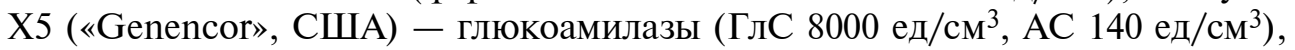

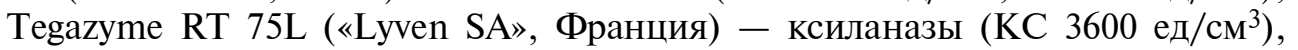
Протооризин («ВНИИПБТ», Россия) - протеаз (ПС 620 ед/см³), Phytaflow

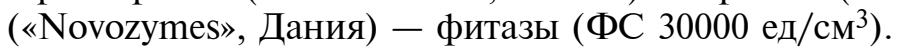

Зерновое сусло готовили в колбах Эрленмейера объемом $750 \mathrm{~cm}^{3}$, содержащих 50 г зерновой муки и $150 \mathrm{~cm}^{3}$ воды (гидромодуль 1:3) и помещенных в водяную баню ПЭ-4300 («Экрос», Россия). Подготовку сусла осуществляли по «мягкой» схеме ферментативно-гидролитической обработки зерна: зерновой замес готовили при $40-50{ }^{\circ} \mathrm{C}$ в течение 30 мин, затем температуру повышали до $85{ }^{\circ} \mathrm{C}$ и выдерживали 120 мин, периодически перемешивая; после охлаждения содержимого колб до $60{ }^{\circ} \mathrm{C}$ его обрабатывали ФП в течение 60 мин. На стадии приготовления зернового замеса для декстринизации крахмала применяли термостабильную $\alpha$-амилазу из расчета 0,6 ед. АС/г крахмала. Для получения зернового сусла осахаривание крахмала и гидролиз некрахмальных полисахаридов в контроле осуществляли ферментными препаратами - источниками глюкоамилазы $(9,0$ ед. ГлС/г крахмала) и ксиланазы $(0,15$ ед. КС/г сырья). В опытных вариантах наряду с ферментами амилолитического, глюкоамилазного и ксиланазного действия вводили ферментный препарат, содержащий фитазу $(1,0 ; 1,5 ; 2,5$ ед. ФС/г сырья), а также ФП протеолитического действия (0,1 ед. ПС/г сырья). Концентрация растворимых сухих веществ в пшеничном сусле составляла $21,1 \%$, в кукурузном - 21,8\%.

Состав основных полимеров зернового сырья, концентрацию зернового сусла, содержание редуцирующих углеводов (РВ) определяли согласно 
инструкции технохимического контроля спиртового производства (29), концентрацию аминного азота $\left(\mathrm{NH}_{2}{ }^{+}\right)$- методом, основанным на способности аминокислот образовывать растворимые медные соединения с суспензией фосфорнокислой меди (30). Динамическую вязкость зернового сусла оценивали посредством вибрационной вискозиметрии с использованием синусоидального вибрационного вискозиметра SV-10 («A\&D Co., Ltd.», Япония) с программным обеспечением Win-CT Viscosity. Изучение ионного состава зернового замеса и сусла проводили, используя систему капиллярного электрофореза серии PrinCE-560 («PrinCE Technologies B.V.», Нидерланды), оснащенную кондуктометрическим детектором (31).

Статистическую обработку данных, полученных не менее чем в трех повторностях, осуществляли с использованием $t$-критерия Стьюдента при р $<0,05$ в программе Statistica 6.0 («StatSoft, Inc.», США). Вычисляли средние значения $(M)$ и стандартные ошибки средних $( \pm \mathrm{SEM})$.

Результаты. При исследовании влияния фитолитической обработки зернового сырья на качественные показатели пшеничного и кукурузного сусла (рис. 1-3) источник фитазы использовали в дозировке 1,0 ед. ФС/г сырья, соответствующей ранее подобранной для подготовки ржаного сусла (28). Действие фитазы способствовало достоверному $(\mathrm{p}<0,05)$ повышению концентрации редуцирующих углеводов в зерновом сусле (на 9,5-11,3 \% относительно контроля), но практически не сказалось на степени гидролиза белков (рис. 1, А, Б). Концентрация аминного азота $\left(\mathrm{NH}_{2}{ }^{+}\right)$в сусле статистически значимо ( $<$ < 05$)$ повышалась только при использовании в составе ферментативного комплекса протеаз: в 1,7 раза при подготовке пшеничного сусла и в 1,9 раза - кукурузного сусла (см. рис. 1, Б).
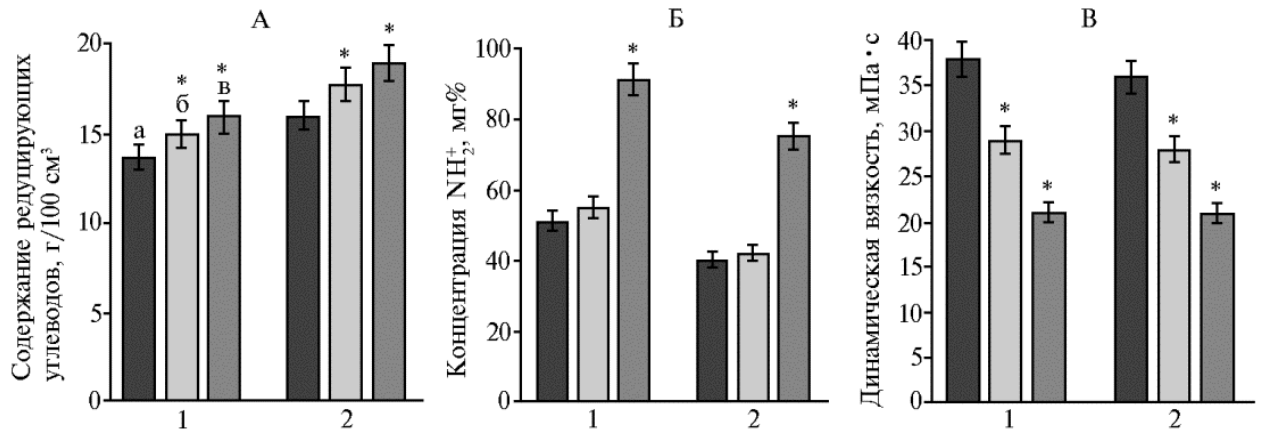

Рис. 1. Содержание редуцирующих углеводов (А), концентрация аминного азота (Б) и динамическая вязкость (В) пшеничного (1) и кукурузного (2) сусла при использовании различных ферментных препаратов: $\mathbf{a}-$ контроль, б - контроль + фитаза (1,0 ед. ФС/г сырья), в - контроль + фитаза (1,0 ед. ФС/г сырья) + протеаза (0,1 ед. ПС/г сырья). Подробное описание вариантов опыта см. в разделе «Методика».

* Различия с контролем (вариант а) статистически значимы при $\mathrm{p}<0,05$.

Результаты исследований реологических свойств зернового сусла подтвердили полученные ранее данные при подготовке ржаного сусла (28): каталитическое действие фитазы обусловливало снижение вязкости пшеничного сусле на 23,7 \%, кукурузного - на 22,2 \% (p < 0,05) (см. рис. 1, В). Использование полного комплекса ферментов, который включал амилазу, глюкоамилазу, ксиланазу, фитазу и протеазу, способствовало достижению более глубокого гидролиза полисахаридов. Концентрация РВ в пшеничном сусле повышалась на 16,8 \%, в кукурузном - на 18,8 \% по сравнению с контролем $(\mathrm{p}<0,05)$ (см. рис. 1, А). При этом было установлено и более существенное понижение вязкости сусла (на 41,7-44,7 \%, p $<0,05$ ) (см. рис. 1, В). 


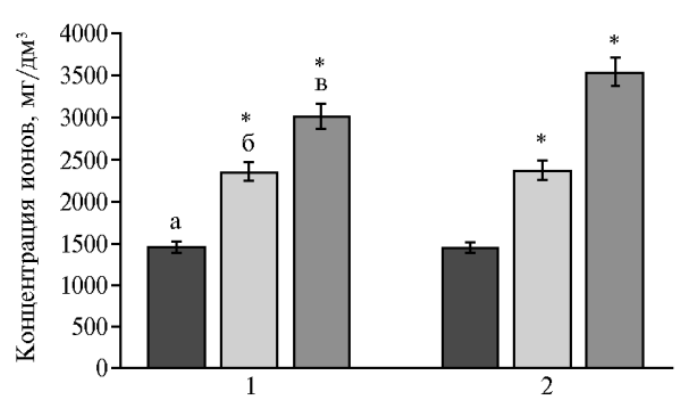

Рис. 2. Содержание общего количества ионов в пшеничном (1) и кукурузном (2) сусле при использовании различных ферментных препаратов: а замес, б - контроль, в - контроль + фитаза (1,0 ед. ФС/г сырья). Подробное описание вариантов опыта см. в разделе «Методика».

* Различия между вариантами б-а, в-а, а также в-б статистически значимы при $\mathrm{p}<0,05$.

Известно, что соли фитиновой кислоты, будучи сильными хелатирующими агентами, образуют с белками устойчивые протеин-фитатные комплексы, а также связывают катионы металлов, что может негативно сказываться на функциях гидролитических металлозависимых ферментов (32). В наших опытах использование фитазы оказывало существенное влияние на увеличение общей концентрации ионов в пшеничном и кукурузном сусле (рис. 2). По сравнению с содержанием ионов в замесе их количество увеличивалось в 2,1-2,4 раза $(\mathrm{p}<0,05)$, а по сравнению с контрольными вариантами сусла - в 1,3-1,5 раза $(\mathrm{p}<0,05)$.

Изучение ионного состава зернового сусла, приготовленного с использованием ферментативных комплексов с включением фитазы, показало, что доля фосфатов, высвобождающихся в результате ее действия, от общего количества идентифицированных ионов в сусле статистически значимо $(\mathrm{p}<0,05)$ увеличилась по сравнению с контролем и составила для пшеницы 40,8 против 31,2 \%, для кукурузы - 30,8 против 11,3 \% (рис. 3). При этом доля ионов калия и магния практически не изменялась.

A

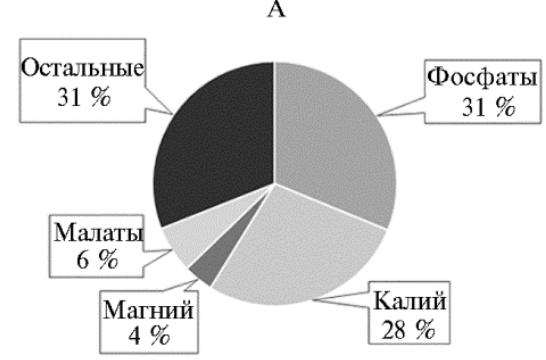

B

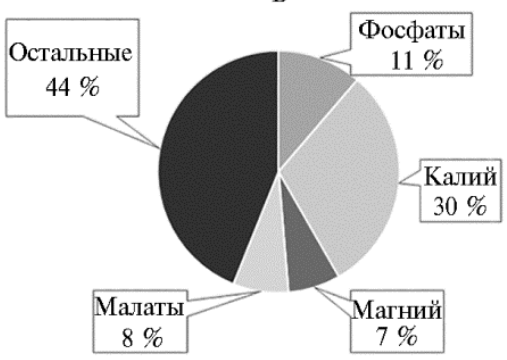

Б

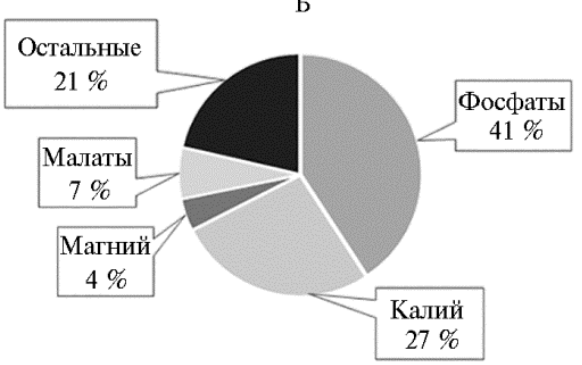

$\Gamma$

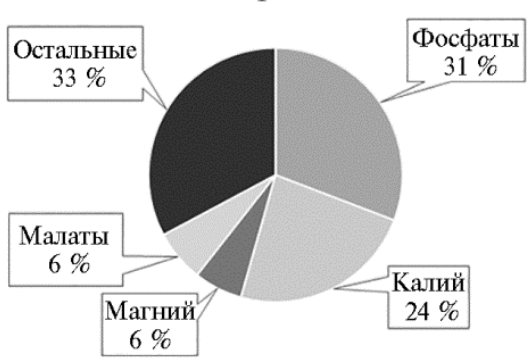

Рис. 3. Содержание (от общего количества, \%) основных идентифицированных ионов в пшеничном (А, Б) и кукурузном (В, Г) сусле при использовании различных ферментных препаратов: А, В - ферментативный комплекс без фитазы (контроль), Б, Г - ферментативный комплекс с фитазой (контроль + фитаза, 1,0 ед. ФС/г сырья). Подробное описание вариантов опыта см. в разделе «Методика».

На следующем этапе мы исследовали влияние дозировки фитазы, входящей в ферментативный комплекс (1,0; 1,$5 ; 2,5$ ед. ФС/г сырья), на качественные показатели пшеничного и кукурузного сусла (рис. 4). 
Каталитическое действие фитазы способствовало высвобождению фосфора (см. рис. 4). Так, в пшеничном сусле, приготовленном с включением в состав ферментативного комплекса фитазы, концентрация фосфатов варьировала от 1145 до 1232 мг/дм³ в зависимости от дозировки фитазы, что в 1,5-1,6 раза (p < 0,05) превышало аналогичные показатели в контроле (см. рис. 4, А). Кроме того, было отмечено некоторое увеличение концентрации ионов калия и магния, которая возрастала при использовании фитазы в дозировке 1,5 ед. ФС/сырья - соответственно на 11 и $17 \%$ (p < 0,05). Более существенное влияние фитаза оказывала при подготовке сусла из кукурузы: концентрация фосфатов в питательной среде увеличилась $(\mathrm{p}<0,05)$ в 3,4-3,9 раза (991-1124 против 290 мг/дм³) (см. рис. 4, В). Концентрация ионов калия и магния повышалась соответственно на 12 и $22 \%$ (p < 0,05). Полученные данные показали, что оптимальная дозировка фитазы составила 1,5 ед. ФС/г сырья. Дальнейшее повышение ее концентрации до 2,5 ед. ФС/г сырья практически не оказывало влияния на показатели зернового сусла.
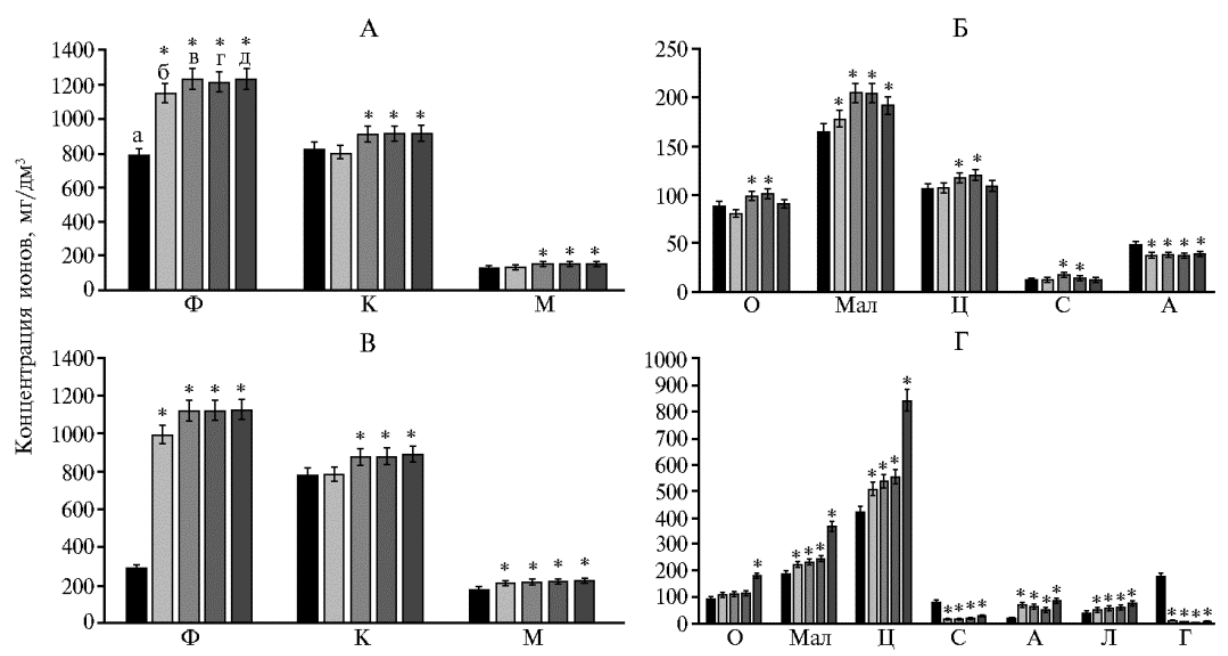

Рис. 4. Ионный состав неорганической и органической природы в пшеничном (А, Б) и кукурузном (В, Г) сусле при использовании различных ферментных препаратов: $а$ - контроль, б - контроль + фитаза $(1,0$ ФС/г), в - контроль + фитаза $(1,5$ ФС/г), г - контроль + фитаза $(2,5$ ФС/г), д - контроль + фитаза $(1,0$ ФС/г) + протеаза $(1,0$ ПС/г); $\Phi-$ фосфаты, $\mathrm{K}-$ калий, $\mathrm{M}-$ магний, О - оксалаты, М - малаты, Ц - цитраты, С - сукцинаты, А - ацетаты, Л лактаты, Г - гликоляты. Подробное описание вариантов опыта см. в разделе «Методика».

* Различия с контролем (вариант а) статистически значимы при p $<0,05$.

Введение фитазы в состав ферментативного комплекса и увеличение ее дозировки влияло не только на концентрацию ионов фосфора, калия и магния в сусле, но и других идентифицированных ионов. Так, по сравнению с контролем статистически значимо $(\mathrm{p}<0,05)$ увеличивалось содержание анионов органических солей (см. рис. 4, Б, Г), таких как малаты - соли янтарной кислоты (для пшеницы 178,2-205,1 против 165,4 мг/дм³ курузы 224,1-367,8 против 189,66 мг/дм³) и цитраты (для кукурузы 510,1844,4 против 422,8 мг/дм³). В пшеничном сусле концентрация солей лимонной кислоты практически не изменялась. Концентрация солей молочной кислоты (лактатов) при подготовке кукурузного сусла увеличивалась в 1,42,0 раза $(\mathrm{p}<0,05)$ в зависимости от дозировки фитазы в составе комплекса. В то же время присутствие в составе ферментативного комплекса фитазы приводило к снижению $(\mathrm{p}<0,05)$ концентрации солей гликолевой кислоты в кукурузном сусле (6,3-10,9 против 178,4 мг/дм³ в контроле). При обработке 
пшеницы лактаты и гликоляты в сусле практически отсутствовали.

При дополнительном введении в состав ферментного комплекса протеаз наблюдалась определенная тенденция к повышению концентрации ионов фосфора, калия и магния в зерновом сусле (см. рис. 4, А, В).

Как упоминалось выше, в последнее время активно исследуются потенциальные возможности применения фитолитических ферментов для увеличения содержания фитатного фосфора в биодоступной форме и повышения усвояемости кормов и продуктов питания $(13,16,22,23)$. При этом недостаточно изучено каталитическое действие фитаз, а также их совместное действие с протеазами в отношении степени деструкции полисахаридов и белковых полимеров зернового сырья, высвобождения катионов и анионов, особенно при приготовлении зернового сусла в бродильных производствах.

В настоящей работе было показано положительное влияние фитолитических и протеолитических ферментов на качественные показатели и изменение ионного состава в пшеничном и кукурузном сусле. По-видимому, в результате биокаталического гидролиза фитиновых веществ, которые, будучи сильными хелатирующими агентами, образуют с белками устойчивые протеин-фитатные комплексы (33), происходило высвобождение не только фосфора, но и углеводных и белковых полимеров, что способствовало повышению доступа гидролитических ферментов к субстратам. Возможно также, что высвобождение катионов металлов, входящих в активные центры этих ферментов, приводило к некоторому повышению их каталитической активности и, соответственно, степени деструкции полимеров зернового сусла.

Наши данные косвенно подтверждают результаты исследований ряда авторов, доказавших роль фитиновой кислоты в ингибировании и регулировании каталитической способности ферментов-металлопротеинов, из которых более изучена ксантиноксидаза $(33,34)$. Так, мы показали, что использование комплекса ферментов, который наряду с карбогидразами включал фитазу и протеазы, способствовало более глубокому гидролизу полисахаридов и белковых веществ. Отмечено статистически значимое $(\mathrm{p}<0,05)$ повышение в пшеничном и кукурузном сусле концентрации РВ соответственно на 16,8 и $18,8 \%$, аминного азота - в 1,7 и 1,9 раза, снижение вязкости - на 41,7 и 44,7\%.

Таким образом, установлено положительное влияние фитолитических ферментов на реологические свойства, изменения ионного состава и содержания фосфора в пшеничном и кукурузном сусле. Использование фитазы при приготовлении зернового сусла способствовало существенному высвобождению ионов, концентрация которых увеличилась более чем в 2 раза по сравнению с их содержанием в зерновом замесе. В результате каталитического действия фитазы увеличивалась концентрация органических солей, таких как оксалаты, малаты, цитраты и сукцинаты в пшеничном сусле и оксалаты, малаты, цитраты и лактаты в кукурузном сусле. При этом в пшеничном и кукурузном сусле концентрация фосфатов повышалась соответственно в 1,6 и 3,9 раза, калия - на 11 и $12 \%$, магния - на 17 и $22 \%$ по сравнению с аналогичными показателями сусла в контроле. Вязкость зернового сусла при использовании фитазы снизилась более чем на $20 \%$. Была подобрана оптимальная дозировка фитазы (1,5 ед. ФС/г сырья) для каталитической конверсии полимеров пшеничного и кукурузного сырья при приготовлении зернового сусла, обеспечивающая максимальное накопление ионов. Синергическое действие фитаз и протеаз усиливало 
эффективность каталитического гидролиза высокомолекулярных полимеров перерабатываемого сырья, способствовало получению зернового сусла, обогащенного углеводами, азотистыми веществами, фосфатами и минералами в биодоступной форме. Полученные результаты свидетельствуют о перспективности дальнейшего изучения каталитического действия фитазного комплекса на активность амилолитических и протеолитических ферментов при обработке полимеров зернового сырья, на метаболизм дрожжевых клеток, их рост и размножение в процессе сбраживания зернового сусла при производстве этанола, а также на повышение усвояемости питательных веществ зерна при откорме сельскохозяйственных животных.

\author{
Всероссийский НИИ пищевой биотехнологии - \\ филиал ФГБУН ФИЦ питания и биотехнологии, \\ 111033 Россия, г. Москва, Самокатная ул., 4 б, \\ e-mail: serbae@mail.ru $\bowtie$, lrimareva@mail.ru,mb_over@mail.ru, \\ ignatova59@list.ru, satella@mail.ru
}

Поступила в редакцию 13 июля 2020 года

Sel'skokhozyaistvennaya biologiya [Agricultural Biology], 2021, V. 56, № 2, pp. 374-383

\title{
INFLUENCE OF PHYTOLYTIC AND PROTEOLYTIC ENZYMES ON CONVERSION OF WHEAT AND CORN GRAIN POLYMERS
}

\author{
L.V. Rimareva, M.B. Overchenko, E.M. Serba ${ }^{凶}$, N.I. Ignatova, N.V. Shelekhova
}

\begin{abstract}
All-Russian Research Institute of Food Biotechnology - a Branch of Federal Research Center for Nutrition, Biotechnology and Food Safety, 4b, ul. Samokatnaya, Moscow, 111033 Russia, e-mail serbae@mail.ru ( $\square$ corresponding author), lrimareva@mail.ru,mb_over@mail.ru, ignatova59@list.ru, satella@mail.ru
\end{abstract}

ORCID:

Rimareva L.V. orcid.org/0000-0003-3097-0836

Overchenko M.B. orcid.org/0000-0003-0191-5897

Ignatova N.I. orcid.org/0000-0002-8416-7478

Serba E.M. orcid.org/0000-0002-1660-2634

The authors declare no conflict of interests

Acknowledgements:

The studies were carried out at the expense of the subsidy for the fulfillment of the state task within the framework of the Fundamental Scientific Research Program of the State Academies of Sciences (topic No. 0529-2019-0066).

Received July 13, 2020 doi: 10.15389 /agrobiology.2021.2.374eng

\begin{abstract}
Grain, in addition to starch, hemicelluloses and protein, is known to be phytic acid and its salts. It has been shown that the use of phytolytic enzymes promotes the release of phosphorus, improves the digestibility of feed nutrients and increases the meat productivity of livestock and poultry. However, the catalytic effect of phytases and their combinations with proteases on degradation of polysaccharides and protein polymers in grain raw materials, on the release of cations and anions, especially in grain wort for the production of alcohol, has been little studied. This work shows for the first time that phytolytic enzymes improve qualitative estimates, rheological properties and change the ionic composition of grain wort by not only releasing phosphates and metal cations, but also by increasing the concentration of organic salt anions. The combined action of phytolytic and proteolytic enzymes on polymers of grain raw materials provides their catalytic degradation to soluble carbohydrates, nitrogenous substances, cations and anions to produce the enriched grain wort. This work aimed to assess the degree of phytolytic and proteolytic conversion of high-molecular-weight polymers in grain wort. For grain wort, $50 \mathrm{~g}$ portions of wheat (Triticum sp.) or corn (Zea mays) grain flour put into Erlenmeyer flasks were added with $150 \mathrm{~cm}^{3}$ of water and incubated in a water bath. At grain batching for starch dextrinization, a thermo-stable $\alpha$-amylase was added ( 0.6 units/g starch). For starch conversion to sugars and hydrolysis of non-starch polysaccharides in the control, we used glucoamylase (9.0 units/g starch) and xylanase ( 0.15 units/g raw material). Phytase (from 1.0 to 2.5 units/g raw material) and a proteolytic enzyme preparation $(0.1$ units/g raw material) were also added. The control was added neither with phytase, nor the proteolytic enzyme. The profiles of the main polymers of grain raw materials, the grain wort concentration, the content of reducing carbohydrates (RC) were determined according to the techno-chemical instructions for the control of alcohol production, the amine nitrogen $\left(\mathrm{NH}_{2}{ }^{+}\right)$concentration was measured by a method based on the ability of amino acids to form soluble copper compounds with a suspension of copper phosphate. The dynamic viscosity of the grain wort was evaluated by vibrational viscometry. The study of the ionic composition of the grain mix and wort was carried out using a PrinCE-560 series capillary electrophoresis system (PrinCE Technologies B.V., Netherlands) equipped with a conductometric detector. The optimal dosage of phytase
\end{abstract}


was 1.5 units/g raw material which ensures the maximum release of ions identified by capillary electrophoresis and the effective conversion of polysaccharides, protein and phytin substances of the grain. It was found that the phytolytic enzymes contributed to a decrease in the viscosity of wheat and corn wort of more than $20 \%$, a 9.5-11.3\% increase in the concentration of reducing carbohydrates, and a 2.1-2.4-fold increase in the concentrations of released ions. The concentration of amino nitrogen in the wort did not change significantly. It was shown that as a result of the phytolytic action, the concentration of not only metal phosphates and cations, but also anions of organic salts, such as oxalates, malates, citrates, and succinates (in wheat wort) and oxalates, malates, citrates, and lactates (in corn wort) increased. A more significant effect of phytase for corn wort was revealed: the concentration of phosphates in the nutrient medium increased 3.9 times vs. 1.6 times for wheat wort, the levels of potassium and magnesium ions were $12 \%$ and $22 \%$ higher, respectively, as compared to the control in which the phytase was not used. The optimal composition of the enzyme complex is proposed which ensures the effective hydrolysis of polysaccharides, phytin and protein substances of processed raw materials. The synergistic effect of phytolytic and proteolytic enzymes enhances the catalytic hydrolysis of high molecular weight polymers of plant origin and enriches the grain wort with carbohydrates, nitrogenous substances, phosphates, and minerals in bioavailable form. Biocatalytic treatment of grain with the developed enzyme complex which, along with amylases and xylanase, contains phytase and proteases, provides a $16.8 \%$ and $18.8 \%$ increase in the concentration of reducing carbohydrates in wheat and corn wort, a 1.7- and 1.9-fold increase in amine nitrogen and a decrease in wort viscosity by $41.7 \%$ and $44.7 \%$, respectively.

Keywords: phytase, protease, wheat raw material, corn raw material, biocatalysis, ions, cations, phosphorus, grain wort.

\section{R E F E R E N C E S}

1. Krivchenko V.A., Turshatov M.V., Solov'ev A.O., Abramova I.M. Pishchevaya promyshlennost', 2019, 4: 53-54 (doi: 10.24411/0235-2486-2019-10027) (in Russ.).

2. Stepanov V.I., Ivanov V.V., Sharikov A.Yu., Amelyakina M.V., Polivanovskaya D.V., Serba E.M. Pishchevaya promyshlennost', 2019, 4: 101-102 (doi: 10.24411/0235-2486-2019-10052) (in Russ.).

3. Ronghou L., Fei S. Impacts of main factors on bioethanol fermentation from stalk juice of sweet sorghum by immobilized Saccharomyces cerevisiae (CICC 1308). Bioresource Technology, 2008, 99(4): 847-854 (doi: 10.1016/j.biortech.2007.01.009).

4. Serba E.M., Abramova I.M., Rimareva L.V., Overchenko M.B., Ignatova N.I., Grunin E.A. Pivo i napitki, 2018, 1: 50-54 (doi: 10.24411/2072-9650-2018-00002) (in Russ.).

5. Du Y., Shi P., Huang H., Zhang X., Luo H., Wang Y., Yao B. Characterization of three novel thermophilic xylanases from Humicola insolens Y1 with application potentials in the brewing industry. Bioresource Technology, 2013, 130: 161-167 (doi: 10.1016/j.biortech.2012.12.067).

6. Vinetsky Y.P., Rozhkova A.M., Sereda A.S., Tsurikova N.V., Nurtaeva A.K., Semenova M.V., Zorov I.N., Sinitsyn A.P. Increase in glucoamylase productivity of Aspergillus awamori strain by combination of radiation mutagenesis and plasmid transformation methods. Applied Biochemistry and Microbiology, 2010, 46(6): 633-640 (doi: 10.1134/S0003683810060128).

7. Benešová K., Běláková S., Mikulíková R., Svoboda Z. Survey of the analytical methods for the phytic acid determination. Kvasny Prumysl, 2013, 59(5): 127-133 (doi: 10.18832/kp2013013).

8. Mikulski D., Kłosowski G. Phytic acid concentration in selected raw materials and analysis of its hydrolysis rate with the use of microbial phytases during the mashing process. Journal of the Institute of Brewing, 2015, 121(2): 213-218 (doi: 10.1002/jib.221).

9. De Carli L., Schnitzler E., Ionashiro M., Szpoganicz B., Rosso N.D. Equilibrium, thermoanalytical and spectroscopic studies to characterize phytic acid complexes with $\mathrm{Mn}$ (II) and $\mathrm{Co}$ (II). Journal of the Brazilian Chemical Society, 2009, 20(8): 1515-1522 (doi: 10.1590/S010350532009000800019).

10. Rimareva L.V., Overchenko M.B., Ignatova N.I., Krivova A.Yu., Serba E. M. Pishchevaya promyshlennost', 2019, 4: 83-85 (doi: 10.24411/0235-2486-2019-10042) (in Russ.).

11. Dost K., Tokul O. Determination of phytic acid in wheat and wheat products by reverse phase high performance liquid chromatography. Analytica Chimica Acta, 2006, 558(1-2): 22-27 (doi: 10.1016/j.aca.2005.11.035).

12. Lee K.-M., Kang H.-S., Yun C.-H., Kwak H.-S. Potential in vitro protective effect of quercetin, catechin, caffeic acid and phytic acid against ethanol-induced oxidative stress in SK-Hep-1 cells. Biomolecules and Therapeutics, 2012, 20(5): 492-498 (doi: 10.4062/biomolther.2012.20.5.492).

13. Greiner R., Konietzny U. Phytase for food application. Food Technology and Biotechnology, 2006, 44(2): 125-140.

14. Lönnerdal B. Phytic acid-trace element $(\mathrm{Zn}, \mathrm{Cu}, \mathrm{Mn})$ interactions. International Journal of Food Science and Technology, 2002, 37(7): 749-758 (doi: 10.1046/j.1365-2621.2002.00640.x).

15. Bretti C., Cigala R.M., Stefano C.D., Lando G., Sammartano S. Interaction of phytate with $\mathrm{Ag}^{+}$, $\mathrm{CH}_{3} \mathrm{Hg}^{+}, \mathrm{Mn}^{2+}, \mathrm{Fe}^{2+}, \mathrm{Co}^{2+}$, and $\mathrm{VO}^{2+}$ : Stability constants and sequestering ability. Journal of Chemical and Engineering Data, 2012, 57(10): 2838-2847 (doi: 10.1021/je300755y). 
16. Nielsen A.V.F., Tetens I., Meyer A.S. Potential of phytase-mediated iron release from cerealbased foods: a quantitative view. Nutrients, 2013, 5(8): 3074-3098 (doi: 10.3390/nu5083074).

17. Yu S., Cowieson A., Gilbert C., Plumstead P., Dalsgaard S. Interactions of phytate and myoinositol phosphate esters (IP1-5) including IP5 isomers with dietary protein and iron and inhibition of pepsin. Journal of Animal Science, 2012, 90(6): 1824-1832 (doi: 10.2527/jas.2011-3866).

18. Zhul'kov A.Yu., Vitol I.S., Karpilenko G.P. Khranenie I Pererabotka Sel'khozsyr'ya, 2009, 5: 5055 (in Russ.).

19. Hesampour A., Ranaei O., Malboobi M.A., Harati J., Mohandesi N. Comparison of biochemical properties of recombinant phytase expression in the favorable methylotrophic platforms of Pichia pastoris and Hansenula polymorpha. Progress in Biological Sciences, 2014, 4(1): 97-111 (doi: 10.22059/PBS.2014.50309).

20. Zhao W., Xiong A, Fu X., Gao F., Tian Y., Peng R. High level expression of an acid-stable phytase from Citrobacter freundii in Pichia pastoris. Applied Biochemistry and Biotechnology, 2010, 162(8): 2157-2165 (doi: 10.1007/s12010-010-8990-4).

21. Tarutina M.G., Kashirskaya M.D., Lazareva M.N., Lapteva A.R., Dobrynin V.Y., Gordeeva T.L., Sineoky S.P. Comparative characteristics of phytases from Citrobacter freundii and Yersinia intermedia expressed in Ogataea polymorpha and Pichia pastoris methylotrophic yeasts. Biotekhnologiya, 2019, 35(6): 51-56 (doi: 10.21519/0234-2758-2019-35-6-51-56).

22. Lenkova T.N., Egorova T.A., Men'shenin I.A., Sysoeva I.G. Ptitsa i ptitseprodukty, 2016, 1: $37-$ 40 (in Russ.).

23. Kulova F.M. Izvestiya Gorskogo gosudarstvennogo agrarnogo universiteta, 2016, 53(1): 71-76 (in Russ.).

24. Sapna, Singh B. Phytase production by Aspergillus oryzae in solid-state fermentation and its applicability in dephytinization of wheat ban. Applied Biochemistry and Biotechnology, 2014, 173(7): 1885-1895 (doi: 10.1007/s12010-014-0974-3).

25. Veiga N., Torres J., Godage H.Y., Riley A.M., Domínguez S., Potter B.V.L., Díaz A., Kremer C. The behaviour of inositol 1,3,4,5,6-pentakisphosphate in the presence of the major biological metal cations. European Journal of Biochemistry, 2009, 14(7): 1001-1013 (doi: 10.1007/s00775-009-0510z).

26. Canan C., Delaroza F., Casagrande R., Baracat M.M., Shimokomaki M., Ida E.I. Antioxidant capacity of phytic acid purified from rice bran. Acta Scientiarum Technology, 2012, 34(4): 457 463 (doi: 10.4025/actascitechnol.v34i4.16358).

27. Kruger J., Oelofse A., Taylor J., Taylor J.R.N. Potential for improvement in yeast nutrition in raw whole grain sorghum and maize lager brewing and bioethanol production through grain genetic modification and phytase treatment. Journal of the Institute of Brewing, 2012, 118(1): 70-75 (doi: 10.1002/jib.86).

28. Polyakov V.A., Serba E.M., Overchenko M.B., Ignatova N. I., Rimareva L.V. The effect of a complex phytase-containing enzyme preparation on the rye wort fermentation process. Foods and Raw Materials, 2019, 7(2): 221-228 (doi: 10.21603/2308-4057-2019-2-221-228).

29. Polyakov V.A., Abramova I.M., Polygalina G.V., Rimareva L.V., Korchagina G.T., Piskareva E.N. Instruktsiya po tekhnokhimicheskomu i mikrobiologicheskomu kontrolyu spirtovogo proizvodstva. Moscow, 2007 [Instructions for the technochemical and microbiological control of alcohol products] (in Russ.).

30. Gosudarstvennaya farmakopeya Rossiiskoi Federatsii, XIII(I), 2015. Available: http://rdocs3.kodeks.ru/document/420324574). No date (in Russ.).

31. Shelekhova N.V., Rimareva L.V. Proizvodstvo spirta i likerovodochnykh izdelii, 2012, 3: 25-27 (in Russ.).

32. De Stefano S., Giuffrè O., Milea D., Rigano C., Sammartano S. Speciation of phytate ion in aqueous solution. Non covalent interactions with biogenic polyamines. Chemical Speciation and Bioavailability, 2003, 15(2): 29-36 (doi: 10.3184/095422903782775235).

33. Muraoka S., Miura T. Inhibition of xanthine oxidase by phytic acid and antioxydant activity. Life Sciences, 2004, 74(13): 1691-1700 (doi: 10.1016/j.lfs.2003.09.040).

34. Abu El-Saad A.S., Mahmoud H.M. Phytic acid exposure alters aflatoxin B1-induced reproductive and oxidative toxcicity in albino rats (Rattus norvegicus). Evidence-based Complementary and Alternative Medicine, 2009, 6(3): 331-341 (doi: 10.1093/ecam/nem137). 